\title{
THE IMPACT OF PERCEIVED ORGANIZATIONAL JUSTICE ON TURNOVER INTENTION: EVIDENCE FROM AN INTERNATIONAL ELECTRONIC CHAIN STORE OPERATING IN TURKEY
}

\author{
Oyku IYIGUN \\ Idil TAMER \\ Istanbul Commerce University, Turkey
}

\begin{abstract}
This paper investigates the impact of organizational justice on the turnover intention of sales representatives of an international electronic chain store operating in Turkey. Data from 156 respondents was used to measure the impact of the perceived organizational justice factor on turnover intention. Exploratory factor analysis has been used to uncover the underlying dimensions of organizational justice. The results of regression analyses indicated that turnover intention of sales representatives have been negatively affected by the perceived level of organizational justice. Some of the control variables were found to have a significant effect on turnover intention.
\end{abstract}

Keywords: Organizational Justice, Distributive Justice, Procedural Justice, Turnover Intention.

\section{INTRODUCTION}

The nature of competitive world markets, new trends in corporate restructuring, slow-growing economies and a strong focus on short-term profits have changed the traditional employment relationship dramatically because organizations are pressured to initiate rapid changes. Today's organizations cannot succeed without the employees' agreement to contribute to the mission and survival of their organization. Employers and employees need to agree on the contributions (Rousseau, 2004).

The main problem faced by any organization is how to provide an environment that facilitates the development of emotional bonds between members in order to keep talented employees in the organization (Ciftcioglu, 2010). Turnover intention is one of the main problems in Human Resources (HR) and organizational management. Turnover not only increases the cost of employing staff, but also diminishes the organization's knowledge capital and weakens its reputation (Liu et al., 2010).

Employees evaluate their experiences at work in terms of whether these experiences are fair and whether organizations show interest as an individual (Lind \& Tyler, 1988). If the employees perceive a decision as being fair, the employment relationship is more likely to comprise higher commitment and greater job satisfaction (Colquitt et al., 2001). When the employees have been subjected to unjust decisions or outcomes, negative reactions occur towards the organization, such as poor performance, absenteeism, and turnover intention (Folger \& Konovsky, 1989).

This study essentially aims to investigate the impact of organizational justice on the turnover intention of the sales representatives of an international electronic chain store operating in Turkey. The remainder of the study is organized as follows. The next section reviews the existing literature. The third section presents the methodology followed by analysis and research findings. Discussion and conclusion are provided in the final section.

\section{LITERATURE REVIEW}

Organizations invest significant effort and resources in attracting, selecting and retaining conscientious, proactive and committed employees. The antecedents of employee turnover and turnover intention have represented a key area of research in the organizational literature (Griffeth et al., 2000; Hom et al., 1992). In order to fully understand how social exchange relationships affect 
turnover decisions, it is important to consider the mechanisms through which perceived organizational justice acts on turnover intention (Dawley et al., 2010).

Turnover intention is one of the main problems in HR and organizational management. Turnover has various results such as increasing the cost of employing staff, diminishing the organization's knowledge capital and damaging its reputation (Liu et al., 2010, Lum et al., 1998). As Moynihan and Pandey (2007) have stated, there are three categories of factors that affect turnover intention. These categories include environment or economy, employees and organization level.

The time always comes when an individual considers the possibility of terminating his or her employment with an organization (Wang et al., 2010). Turnover intention can be defined as a conscious psychological willingness to leave an organization (Tett \& Meyer, 1993) and as an employee's intention to leave the current organization and look for other employment alternatives. Hom and Griffeth (1991) define turnover intention as a construct that includes three components: intent to search, thinking of quitting and intent to quit. Turnover intention is accepted as the main antecedent of an employee's turnover behavior (Ciftcioglu, 2010). Turnover intention can be described as the cognitive process of thinking, planning and desiring to quit a job (Ahmad et al., 2010). In other words, turnover refers to employee withdrawal from an organizational position or a career path. Cai and Zhou (2009) suggest that dissatisfaction with the work environment is an important precursor of an employee's decision to leave the organization or profession concerned.

There are diverse factors affecting turnover, which can make it difficult to predict turnover behavior accurately. As Bedeian et al. (1991) have stated, the intention to leave has been consistently correlated with turnover (Wang et al., 2010). As Williams and Hazer (1986), Farkas and Tetrick (1989) and Allen and Meyer (1996) have suggested, job satisfaction and organizational commitment reduce turnover intention and that is why researchers should identify emotional responses and psychological factors in the turnover process (Wang et al., 2010). The fairness associated with HR practices has been related to a number of work attitudes including organizational commitment (Ogilvie, 1986; Brockner et al., 1988; Brockner et al., 1990), job dissatisfaction and turnover (Aquino et al., 1997). As a consequence of these outcomes, it has been suggested that organizational justice research possesses a significant societal value (Sashkin \& Williams, 1990; Sabbagh et al., 1994). Masterson et al. (2000) have argued that there is "substantial evidence that fairness is an important dimension affecting employees' actions and reactions within organizations" (Haar \& Spell, 2009).

Organizational justice describes the individual's and group's perception of the fairness of treatment received from an organization and their behavioral reaction to such perceptions (James, 1993; Aryee et al., 2002). Organizational justice theories center on perceived fairness in the workplace (Greenberg, 1990). The concept is generally analyzed in three categories: distributive, procedural and interactional justice. Distributive justice describes the perceived fairness of the means used to determine those outcomes employees receive; procedural justice refers to the perceived fairness of the means used to determine those outcomes, and interactional justice refers to the quality of interpersonal treatment received at the hands of decision-makers (Bies \& Moag, 1986; Colquitt et al., 2001; Cropanzano \& Greenberg, 1997).

Since its inception, distributive justice has been rooted in Adams' (1963) equity theory. Adams' theory of equity stipulates that a fair balance must be created between an employee's inputs and an employee's outputs. In understanding Adams' (1963) theory, it is important to recognize that the theory is created on the belief that employees become de-motivated if they feel that inputs outweigh outputs. Inputs relate to items such as hard work, enthusiasm, skill level, commitment and dedication, whereas outputs are the rewards achieved such as pay, benefits, and recognition. Based on this theory, Adams postulated that when there is a perceived equal balance between inputs and outputs, a strong and a productive relationship is created which inevitably results in a motivated employee (Biby, 2008). Adams used social exchange theory framework to evaluate fairness. Social exchange theory asserts that exchanges between employer and employee can lead to obligations, and meeting these obligations can evoke positive reactions, while unfulfilling obligations may lead to negative outcomes (Blau, 1964). This theory suggests that employees feel obligated to reciprocate when they personally benefit from their employers actions, such as fair pay and rewards system offered by their organization (Haar \& Spell, 2009). Additionally, as Adams pointed out, employees will judge their outcomes by their perception of what other employees performing the same job should receive (Biby, 2008). 
Distributive justice refers to the perceived fairness of the outcomes employees receive and explains how employees react to the nature, and distribution of organizational rewards. At this point distributive justice ignores the procedures or means through which these ends are established, so the literature has provided the term procedural justice to explain the perceived fairness of the means used to determine those outcomes (Folger \& Konovsky, 1989), enabling a more integrated approach. It was Leventhal et al. (1980) who have succeeded to bring out procedural justice to a wider field and suggested that there are at least six procedural rules that individuals use in judging fairness. These six procedural rules are; a) procedures that are consistent across individuals and over time (consistency), b) decisions that are grounded on good information and informed opinion (accuracy), c) opportunities in place that can be used to modify or reverse decisions based on inaccurate information (correctability), d) allocation processes that represent the concerns of all important subgroups and individuals (representativeness), e) allocation processes that are compatible with prevailing moral and ethical standards (ethically), f) no personal self-interest and blind allegiance that may narrow conceptions. In short, as Dirks and Ferrin (2002) state, "procedural justice deals with the processes that lead to decision outcomes". Any violation by a decision-maker or an organization can lead to perceptions of procedural injustice (Leventhal et al., 1980; Kickul et al., 2005).

Interactional justice, as organizational justice's third component deals with the way the parties approach each other in an organization and focuses on the interpersonal treatment subordinates receive from management. In this sense, procedural justice examines the process by which rewards are allocated, whereas interactional justice is concerned with peoples' perception of interpersonal treatment (Elicker et al., 2006). Interactional justice reflects the social side of procedural justice is the interpersonal treatment people receive as procedures are enacted, which is fostered when decision makers treat people with respect and sensitivity and explain the rationale for decisions thoroughly (Bies \& Moag, 1986). This construct has further developed and divided into two sub-dimensions- one of which is interpersonal justice. Interpersonal justice is concerned with the degree of politeness, dignity and respect exhibited by authorities or third parties involved in executing procedures or determining outcomes. The second one is informational justice which focuses on the explanations provided to employees that convey information about why procedures were used in a certain way or why outcomes were distributed in a certain fashion.

A study conducted by McFarlin and Sweeney (1992) tested an interaction pattern suggested by referent cognitions theory which states that employees evaluate work experiences reflecting on "what might have been" under different circumstances (Folger, 1986). Consistent with other studies (Samad, 2006a; Samad, 2006b; Folger \& Kanovosky, 1989) both distributive and procedural justice were found to be significant predictors of each outcome variable, including job satisfaction, organizational commitment, and employee intention to leave (Biby, 2008). Researchers examining distributive and procedural justice simultaneously noted that there are differences in the strengths of their predictive abilities (Folger and Konovsky, 1989; Harvey \& Haines, 2005; McFarlin and Sweeney, 1992). McFarlin and Sweeney suggested procedural justice to be a more potent predictor of organizational outcomes, while distributive justice to be a stronger predictor of individual outcomes. They considered turnover and satisfaction to be individual outcomes rather than organizational outcomes (Harris et al., 2007).

The literature suggests that organizational justice could be related to many work outcomes, including but not limited to job satisfaction, organizational commitment, and employee turnover intention (Colquit, 2001). Research has consistently found the three dimensions of organizational justice to be related, albeit differentially, to employee work-related attitudes and behaviors (Colquitt et al., 2001; Aryee et al., 2002). Welbourne et al. (1995) noted that organizational justice dimensions have been found to be important predictors of a wide variety of outcomes, including satisfaction with leaders, reactions to performance appraisals (Greenberg, 1986; Kidwell and Bennett, 1994; Thomas and Bretz, 1994), and the like hood of managers to use new systems (Blancero and Dyer, 1996). Situations where justice has been lacking have been linked with negative consequences (Chen, 2000), such as lower performance, higher turnover intentions, decreased organizational commitment, theft, and decreased citizenship behaviors (Cropanzona \& Greenberg, 1997; Folger \& Cropanzona, 1998; Greenberg 1990c, 2002), reduced job performance (Pfeffer \& Langton, 1993), reduced quality of work (Cowherd \& Levine, 1992), frustration, reduced self-image, and moral outrage (Greenberg, 1990b).Furthermore, perceived injustices have been linked to other human resource programs such as drug-testing programs and pay-rise decisions (Folger \& Konovsky, 1989; Haar \& Spell, 2009). In line with the previous literature, two main hypotheses have been developed: 
H1: There is a negative and significant relationship between distributive justice and turnover intention.

H2: There is a negative and significant relationship between procedural justice and turnover intention.

\section{METHOD}

As Gibbert (2010) indicates, it is very important to pay careful consideration to the choice of a research method, research design, site and factors that limit the study at the beginning of any study. The choice of method is critical because it impacts the approaches and techniques for collecting and analyzing data.

This study seeks to examine the impact of organizational justice on turnover intention by using quantitative data analysis. Two different standard scales developed and used earlier in the extant literature were adopted. Each scale is composed of multiple items, with response categories ranging from 1-5 on a Likert-type scale. Turnover intention scale was drawn from Cook et al. (1981) and is composed of 4 items. Organizational justice scale was adopted from Niehoff and Moorman (1991) and is composed of 20 items.

The survey of the research was administered in an international electronic chain store operating in Turkey. The questionnaires were distributed during group sessions, facilitated by the HR department team. In these sessions, employees were informed about the aim of the study. More specifically, it was explained about the interest in contemporary employment relationships and how these are experienced through organizational justice. The participants completed confidential questionnaires during work hours. The final sample consisted of 156 sales representatives of the international electronic chain store. Exploratory factor analysis (EFA) was used to produce underlying dimensions of organizational justice.

As it is not easy to obtain actual turnover rates, in measuring turnover intention, we followed the empirical studies in which turnover intention was set instead as the predictor of actual turnover. Although turnover intention cannot completely replace actual turnover, measuring turnover intention rather than actual turnover would also allow us to ascertain the employees' emotional attitude because whether or not employees will quit depends on the conditions and environment in the organization (Moynihan and Pandey, 2007; Liu et al., 2010).

The following control variables were also used: Education and tenure of the respondents, age, work experience, total work experience, gender and marital status. Education was measured by an ordinal scale ranging from high school, vocational to university. Age was measured as a continuous variable denoting a number of years. Work experience and total work experience were measured by an ordinal scale including 4 categories. Gender and marital status were measured categorically.

Figure 1 shows the research model of the study.

\section{Figure 1. Conceptual Framework}

\section{Organizational Iustice}

Outcomes

\section{Control Variables}

- Gender

- Marital Status

- Age

- Education

- Work Experience

- Total Work Experience

\section{ANALYSIS \& RESEARCH FINDINGS}

Of the 180 questionnaires distributed, 156 completed questionnaires were returned, representing a response rate of $86.6 \%$. The distributions of respondents were as follows: $71.8 \%$ were men and $28.2 \%$ were women; $57.7 \%$ were single and $42.3 \%$ were married. Of the sample, $74.4 \%$ were in the under 30 
year old age bracket and $71.2 \%$ had obtained a high school education. As shown in Table $1,47.4 \%$ of the sample held an organizational tenure of between one and three years and $30.8 \%$ had a total tenure up to five years. Table 1 shows the sample characteristics of the questionnaire respondents.

Table 1. Sample Characteristics

\begin{tabular}{|c|c|c|c|}
\hline \multicolumn{2}{|l|}{ Characteristics } & Number & $\%$ \\
\hline \multirow{2}{*}{ Gender } & Female & 44 & 28.2 \\
\hline & Male & 112 & 71.8 \\
\hline \multirow{2}{*}{ Marital Status } & Single & 90 & 57.7 \\
\hline & Married & 66 & 42.3 \\
\hline \multirow{2}{*}{ Age } & Under 30 & 116 & 74.4 \\
\hline & Over 30 & 40 & 25.6 \\
\hline \multirow{3}{*}{ Education } & High School & 111 & 71.2 \\
\hline & Vocational School & 22 & 14.1 \\
\hline & University Graduate & 23 & 14.7 \\
\hline \multirow{4}{*}{ Work Experience } & $0-12$ months & 50 & 32.1 \\
\hline & 13-36 months & 74 & 47.4 \\
\hline & $37-60$ months & 31 & 19.9 \\
\hline & Over 60 months & 1 & 0.6 \\
\hline \multirow{4}{*}{ Total Work Experience } & $0-60$ months & 48 & 30.8 \\
\hline & 61-84 months & 25 & 16.0 \\
\hline & 85-120 months & 33 & 21.2 \\
\hline & Over 120 months & 50 & 32.1 \\
\hline & $N$ & \multicolumn{2}{|c|}{156} \\
\hline
\end{tabular}

In order to undertake EFA, it is necessary to have relation between the variables and it is checked with Barlett's test of sphericity and Kaiser-Meyer-Olkin (KMO) tests. Moreover, it is important to monitor Anti-Image and Measures of Sampling Adequacy (MSA) values. Of the study, KMO value (0.925) and Barlett's test $(\chi 2=2647.481$ and $p<0.001)$ are sufficient to perform EFA. The relationships among the study's constructs were tested using regression analyses.

In this study, all items and components were tested by the Cronbach Alpha reliability test, which is generally used as a measure of the internal consistency or reliability of a psychometric test score for a sample. The reliability coefficient of the scale has been determined a satisfactory level such that $\alpha=0.89$; this value is highly satisfactory with the recommended 0.70 threshold (Nunnally, 1978; Nunnally and Bernstein, 1994). The scale has a total variance of $68.53 \%$ explained. The variables existing in the scale were tested and only one item was removed before the analyses process ("employees may disagree with their employers because of a business decision or may ask top management to renegotiate the decision"). The results of factor analyses showed that the independent variables are gathered in two factors. Factor 1 consists of five items about distributive justice with an internal consistency reliability coefficient Alpha of $\alpha=0.81$. Factor 2 includes not only procedural justice but also interactional justice with 14 items with an internal consistency reliability coefficient Alpha of $\alpha=0.96$. Schappe (1998) suggests that procedural justice is about the perception of fairness in decision making processes. However two other dimensions such as structural ("formal process characteristics") and interactional justice ("how an employee is treated during processes") have been proposed as sub-dimensions of procedural justice. The scale structure that was obtained with factor analysis was evaluated with the Kolmogorov-Smirnov test which quantifies a distance between the empirical distribution function of the sample and the cumulative distribution function of the reference distribution (Zehir et al., 2011), or between the empirical distribution functions of two samples, and it was seen that $t$ values of all the variables were at the sufficient level for our sample that prove the distribution of the data is statistically normal. 
Table 2 shows descriptive statistics and correlation coefficients of independent variables in the study. The pairwise correlations do not seem to present serious multicollinearity problems for the multivariate analysis, as none of the variables have correlation coefficients above 0.50 (Hair et al., 2006).

Table 2. Descriptive Statistics and Correlation Coefficients of Variables

\begin{tabular}{|l|c|c|c|c|c|c|c|c|c|c|}
\hline Variable name & Mean & S.D. & $\mathbf{1}$ & $\mathbf{2}$ & $\mathbf{3}$ & $\mathbf{4}$ & $\mathbf{5}$ & $\mathbf{6}$ & $\mathbf{7}$ & $\mathbf{8}$ \\
\hline 1. Distributive justice & 0.00 & 1.00 & 1.00 & 0.00 & -0.14 & 0.01 & -0.00 & -0.01 & -0.11 & -0.14 \\
\hline 2. Procedural justice & 0.00 & 1.00 & & 1.00 & -0.03 & $0.19^{*}$ & -0.12 & 0.08 & 0.04 & 0.04 \\
\hline 3. Education & 1.43 & 0.73 & & & 1.00 & -0.10 & -0.10 & -0.12 & 0.09 & 0.05 \\
\hline 4. Age & 1.25 & 0.43 & & & & 1.00 & $0.20^{* *}$ & $0.45^{* *}$ & 0.07 & $-0.29^{* *}$ \\
\hline 5. Work experience & 1.89 & 0.73 & & & & & 1.00 & $0.33^{* *}$ & 0.00 & $-0.18^{*}$ \\
\hline 6. Total work experience & 2.54 & 1.23 & & & & & & 1.00 & 0.13 & $-0.27^{* *}$ \\
\hline 7. Gender & 1.72 & 0.45 & & & & & & & 1.00 & -0.04 \\
\hline 8. Marital status & 1.58 & 0.49 & & & & & & & & \\
\hline
\end{tabular}

Notes:

$* \mathrm{p}<0.05 ; * * \mathrm{p}<0.01$

$\mathrm{N}=156$

In order to test the study's hypotheses, two regression models were estimated with the dependent variable turnover intention. The effects of independent variables on the dependent variable are shown in Table 3 respectively. A set of two models were tested for the dependent variable. As the first step, control variables were entered. Among these variables, education $(\beta=0.24: \mathrm{p}<0.05)$, work experience $(\beta=0.32: p<0.05)$ and marital status $(\beta=0.32: p<0.05)$ were found to have significant effects. The regression model is significant as a whole $(\mathrm{F}=3.59$ : $\mathrm{p}<0.01)$ and it explains $13 \%$ of the variation in turnover intention. The hypothesized variables were then tested in Model 2, as shown in Table 3, respectively.

Table 3. Regression Results

\begin{tabular}{|l|c|c|c|c|}
\hline Variable name & \multicolumn{2}{|c|}{ Model 1 } & \multicolumn{2}{c|}{ Model 2 } \\
\hline Independent variables & B & Std. Error & B & Std. Error \\
\hline Distributive Justice & & & $-0.37^{* *}$ & 0.06 \\
\hline Procedural Justice & & & $-0.47^{* *}$ & 0.06 \\
\hline Control Variables & & & & \\
\hline Education & $0.24^{*}$ & 0.10 & $0.15^{*}$ & 0.08 \\
\hline Age & -0.37 & 0.20 & -0.14 & 0.16 \\
\hline Work Experience & $0.32^{*}$ & 0.11 & $0.19^{*}$ & 0.09 \\
\hline Total Work Experience & 0.02 & 0.07 & 0.02 & 0.05 \\
\hline Gender & 0.13 & 0.17 & 0.08 & 0.13 \\
\hline Marital Status & $0.32^{*}$ & 0.16 & $0.28^{*}$ & 0.13 \\
\hline Intercept & \multicolumn{2}{|c|}{$-1.28^{*}$} & \multicolumn{2}{c|}{$-1.07^{*}$} \\
\hline F statistic & \multicolumn{2}{|c|}{$3.59^{* *}$} & \multicolumn{2}{c|}{0.47} \\
\hline R-square & \multicolumn{2}{|c|}{0.09} & \multicolumn{2}{c|}{0.44} \\
\hline Adjusted R-square & \multicolumn{2}{|c|}{0.06} \\
\hline
\end{tabular}

Notes:

$* \mathrm{p}<0.05 ; * * \mathrm{p}<0.01$

$\mathrm{N}=156$

The effects of organizational justice on turnover intention are shown in Model 2. The impact of distributive justice on turnover intention was investigated and it was found that distributive justice has a negative and significant impact on turnover intention $(\beta=-0.37$ : $\mathrm{p}<0.01)$. The impact of procedural justice on turnover intention was also investigated and it was found that procedural justice has a negative and significant impact on turnover intention $(\beta=-0.47: \mathrm{p}<0.01)$. The regression model is significant as a whole $(\mathrm{F}=16.15: \mathrm{p}<0.01)$ and it explains $47 \%$ of the variation in turnover intention. The findings show there is a strong support for $\mathrm{H} 1$ and $\mathrm{H} 2$. 


\section{DISCUSSION \& CONCLUSION}

This study aimed at assessing the importance of organizational justice on turnover intention by investigating the interrelationships among variables. The findings of the study demonstrated strong support for the impact of organizational justice on turnover intention.

Specifically, our findings showed that distributive justice and procedural justice were negatively and significantly related to turnover intention while demographic characteristics of education, tenure and marital status were positively and significantly related to turnover intention. The results indicate that organizational justice plays an important role for the employees' fairness perception.

In the past, many organizations and scholars focused on developing feelings of commitment and organizational citizenship behaviors employees performed. Organizational commitment denotes an emotional attachment and identification with an organization. Organizational citizenship behaviors embody non-required and uncompensated actions such as punctuality, attendance, aiding coworkers, voluntarily assuming ad-hoc tasks and assisting management in implementing new tasks (Dawley et al., 2010). However, over the next 20 years it is likely that the idea of developing emotional ties to the organization will not be enough, and organizations will no longer have the luxury of being concerned with employees performing extra-role behaviors. Instead, employee retention will become increasingly important as the competition among organizations for highly skilled workers will likely become fierce. This will make it imperative for organizations to look for other ways to develop loyalty and commitment among their workforces. Our findings suggest that organizations should consider taking actions that will raise employees' perceived organizational justice while making employees generally more comfortable in their current situation. For example, organizations may wish to further connect with their employees by raising the perception of fairness in decision making processes. Employees, on the other hand, should be aware that organizations will more likely be concerned with the increased degree of politeness, dignity and respect in executing processes. In the long run, efforts by organizational decision makers to increase distributive and procedural justice may lead to a winwin situation in which organizations will be able to decrease turnover.

The aim of the study described in this paper was to increase management's understanding of the employee turnover process and, in doing so, improve the management of employee turnover statistics and its associated costs. The costs associated with the departure and replacement of employees can have a significant and detrimental effect on an organization (Bluedorn, 1982). HR practices could benefit from the predictive validity this study provides and it could be used in the reduction of employee turnover. The results of this study could also be used to address some of the talent management and human capital issues of today's organizations. The practical implications of the study will, therefore, impact on all the HR activities, ranging from employee entrance level right through to employee exit level. Allen and Meyer (1996) found that turnover intentions were negatively associated with organizational commitment. This indicated that attention needs to be given to the strategies that are used currently to prevent employee turnover. From a managerial point of view, the results suggest that management should give importance to organizational justice in the organization in terms of reciprocity, decision making processes, politeness, dignity and respect. HR professionals need to focus their efforts on reducing employee turnover in order for businesses and industries to operate efficiently.

A number of important limitations need to be considered. First, attempts to explain an increase or decrease in the level of turnover intention can involve many factors. Organizational justice and demographic characteristics are the factors that were used in this study; however, there are many other factors that could be considered or examined. This study might also have been limited by the quantification methods that were used. Future researchers could include qualitative measures for obtaining additional information from the participants. Generalizing the opinion of individuals could provide a more complete picture of the relationships between organizational justice and turnover intention. Additionally, the data collection of the research was restricted to 156 respondents of an international electronic chain store operating in Turkey and its generalizability is therefore limited (Schwab, 2005). With a small sample size, caution must be applied, as the findings might not be transferable to nationwide. A more serious concern is common method bias due to the self-report measurement of all variables (Podsakoff, MacKenzie, Lee, \& Podsakoff, 2003). Through more scientific and rigorous research such as longitudinal design and larger samples from other companies, sectors or industries operating in different cultural, environmental and political conditions greater 
understanding of organizational justice will be obtained which will provide more information on management practice. Another important constraint includes the fact that social science surveys are susceptible to hallo effects as a consequence of the used methodology. Hallo effects may arise from sampling and non-sampling errors and as mentioned in the paper, specific measures were taken to identify the source and limit such effects (Zehir et al., 2011). The findings might have been much more reliable if the survey had been implemented on a nationwide basis. Furthermore, our contributions to management research open up possibilities for future research. Despite these limitations, this study provides important implications from theoretical and practical perspectives. This study clinches the argument regarding the important role of organizational justice related variables (distributive justice and procedural justice) on turnover intention. 


\section{REFERENCES}

Adams, J. S. (1963). "Toward an understanding of inequity", Journal of Abnormal and Social Psychology, Vol.67, pp. 422-436.

Ahmad, S., Shahzad, K., Rehman, S., Khan, N. A. and Shad, I. U. (2010). "Impact of organizational commitment and organizational citizenship behavior on turnover intentions of call center personnel in Pakistan", European Journal of Social Sciences, Vol.17(4), pp. 585-591.

Allen, N. J. \& Meyer, J. P. (1996). "Affective, continuance, and normative commitment to the organization: An examination of construct validity", Journal of Vocational Behavior, Vol.49, pp. 252276.

Aquino, K., Griffeth, R. W., Allen, D. G., and Hom, P. W. (1997). "Integrating justice into the turnover process: A test of a referent cognitions model", Academy of Management Journal, Vol.40, pp. 12081227.

Aryee, S., Budhwar P. S., Chen Z. X. (2002). "Trust as a mediator of the relationship between organizational justice and work outcomes: Test of a social exchange model", Journal of Organizational Behavior, Vol.23, pp. 267-285.

Bedeian, A., Kemery, E., \& Pizzolatto, A. (1991). "Career commitment and expected utility of present job as predictors of turnover intentions and turnover behavior", Journal of Vocational Behavior, Vol.39, pp. 331-343.

Biby, C. L. (2008). "Should I stay or should I leave? Perceptions of age discrimination, organizational justice and employee attitudes on intention to leave", Journal of Applied Management and Entrepreneurship, Vol.13(2), pp. 63-86.

Bies, R. J., and Moag, J. S. (1986). "Interactional justice: Communication criteria of fairness" in Research on Negotiations in Organization, Vol.1, (ed. R. J. Lewicki, B.H. Sheppard and M.H. Bazerman, Greenwich), Ct: JAI Press.

Blancero, D. and Dyer, L. (1996). "Due process for non-union employees - the influence of system characteristics on fairness perceptions", Human Resource Management, Vol.35(3), pp. 343-359.

Blau, P. (1964). Exchange and Power in Social Life, New-York: Wiley.

Bluedorn, A.C. (1982). "Managing turnover strategically”, Business Horizons, March-April, pp. 6-12.

Brockner, J., Grover, S. L. and Blonder, M. D. (1988). "Predictors of survivors' job involvement following layoffs: A field study", Journal of Applied Psychology, Vol.73, pp. 436-442.

Brockner, J., Grover, S. L., Reed, T., Dewitt, F. (1990). "When is it especially important to explain why: Factors affecting the relationship between managers' explanations of a layoff and survivor's reactions to the layoff", Journal of Experimental Social Psychology, Vol.26, pp. 389-407.

Cai, C. \& Zhou, Z. (2009). "Structural empowerment, job satisfaction and turnover intention of Chinese clinical nurses”, Nursing and Health Sciences, Vol.11, pp. 397-403.

Chen, Z. X., \& Francesco, A. M. (2000). "Employee demography, organizational commitment, and turnover intentions in China: Do cultural differences matter?", Human Relations, Vol.53(6), pp. 869887.

Ciftcioglu, A. (2010). "The relationship between perceived external prestige and turnover intention: An empirical investigation", Corporate Reputation Review, Vol.13(4), pp. 248-263.

Colquitt, J. A., Conlon, D. E., Wesson, M. J., Porter, C. O. L. H. and Ng, K. Y. (2001). "Justice at the millennium: A meta-analytic review of 25 years of organizational justice research", Journal of Applied Psychology, Vol.86, pp. 425-45.

Cook, J. D., Hepworth, S. J., Wall, T. D. and Warr, P. B. (1981). The Experience of Work a Compendium and Review of 249 Measures and Their Use, US: Academic Press.

Cowherd, D. M., and Levine, D. L. (1992). "Product quality and pay equity between lower level employees and top management: An investigation of distributive justice theory", Administrative Science Quarterly, Vol.37, pp. 302-320. 
Cropanzano R. and Greenberg, J. (1997). "Process in organizational justice: Tunneling through the maze", International Review of Industrial and Organizational Psychology, (ed. C.L. Cooper and I.T. Robertson), New York: Wiley, pp. 317-372.

Dawley, D., Houghton, J. D. and Bucklew, N. S. (2010). "Perceived organizational support and turnover intention: The mediating effects of personal sacrifice and job fit", Journal of Social Psychology, Vol.150(3), pp. 238-257.

Dirks, K. T. \& Ferrin, D. L.(2002), 'Trust in leadership: Meta- analytic findings and implications for research and practice", Journal of Applied Psychology, Vol.87(4), pp. 611-628.

Elicker, J. D., Paul E. L. and Rosalie J. H. (2006). "The role of leader-member exchange in the performance appraisal process," Journal of Management, Vol.32, pp. 531-551.

Farkas, A. J., \& Tetrick, L. E. (1989). "A three-wave longitudinal analysis of the causal ordering of satisfaction and commitment on turnover decisions", Journal of Applied Psychology, Vol.74(6), pp. 855-868.

Folger, R. \& Konovsky, M.A. (1989). "Effects of procedural and distributive justice on reactions to pay raise decisions", Academy of Management Journal, Vol.32(1), pp. 115-130.

Folger, R. (1986). "Rethinking equity theory: A referrent cognitions model", In H. W. Bierhoff, R. L. Cohen, J. Greenberg ed., Justice in Social Relations, NY: Plenum, pp. 145-162.

Folger, R. \& Cropanzona, R. (1998). Organizational Justice and Human Resource Management, Thousand Oaks, CA: Sage.

Gakovic, A. \& Tetrick, L. E. (2003). "Psychological contract breach as a source of strain for employees", Journal of Business and Psychology, Vol.18, No.2, Winter, pp. 235-246.

Gibbert, M. (2010). Strategy Making In A Crisis From Analysis To Imagination, UK: Edward Elgar Publishing.

Greenberg, J. (1987). "A taxonomy of organizational justice theories", Academy of Management Review, Vol. 12, pp. 9-22.

Greenberg, J. (1986). "Determinants of perceived fairness of performance evaluations", Journal of Applied Psychology, Vol.71, pp. 340-342.

Greenberg, J. (1990). "Managing impressions of organizational justice” in Research in Organizational Behavior, Vol.13, (ed. B.M. Straw and L. Cummings, Greenwhich, CT: JAI Press.

Greenberg, J. (1990b). "Organizational justice: Yesterday, today and tomorrow", Journal of Management, Vol.16(2), pp. 399-432.

Greenberg, J. (1990c). "Employee theft as a reaction to underpayment inequity: The hidden cost of pay cuts", Journal of Applied Psychology, Vol.75, pp. 561-568.

Griffeth, R. W., Hom, P. W., \& Gaertner, S. (2000). "A meta-analysis of antecedents and correlates of employee turnover: Updated moderator tests and research implications for the next millennium", Journal of Management, Vol.26, pp. 463-488.

Haar, J. M. and Spell, C. S. (2009). "How does distrubutive justice affect work attitudes? The moderating effects of autonomy", International Journal of Human Resource Management, Vol.20(8), pp. 1827-1842.

Hair, J. F., Black, W. C., Babin, B. J., Anderson, R. E., and Tatham, R. L. (2006). Multivariate Data Analysis. 6th Ed., Upper Saddle River, New Jersey, Pearson.

Harris, K. J., Andrews, M. C. and Kacmar, K. M. (2007). "The moderating effects of justice on the relationship between organizational politics and workplace attitudes", Journal of Business and Psychology, Vol.22, pp. 135-144.

Harvey, S. and Haines, V. Y. (2005). "Employer treatment of employees during a community crisis: The role of procedural and distributive justice", Journal of Business and Psychology, Vol.20, pp. 53-68.

Hom, P. W. and Griffeth, R. W. (1991). "Structural equations modeling test of a turnover theory: Cross-sectional and longitudinal analyses", Journal of Applied Psychology, Vol.76, pp. 350-367. 
Hom, P. W., Caranikas-Walker, F., Prussia, G. E., \& Griffeth, R. W. (1992). "A metaanalytical structural equations analysis of a model of employee turnover", Journal of Applied Psychology, Vol.78, pp. $890-909$.

James, K. (1993). "The social context of organizational justice: Cultural, intergroup and structural effects on justice behaviors and perceptions", In Justice in the Workplace: Approaching Fairness in Human Resource Management, pp. 21-50, Cropanzano, R. (ed.). Erlbaum: Hillsdale, CT.

Kickul J., Gundry, L. K. and Posig M. (2005). "Does trust matter? The relationship between equity sensitivity and perceived organizational justice", Journal of Business Ethics, Vol.56, pp. 205-218.

Kidwell, R. E. and Bennett, N. (1994). "Employee reactions to electronic systems", Group and Organization Management, Vol.19, pp. 203-218.

Leventhal, G. S., Karuza J, Fry, W. R.. (1980). "Beyond fairness: A theory of allocation preferences", in G. Miluka (ed.), Justice and Social Interaction, Springer New York, pp. 167-218.

Lind, E. A., Tyler, T. R. (1988). The Social Psychology of Procedural Justice, NY: Plenum Press.

Liu, B., Liu, J., Hu, J. (2010). "Person-organization fit, job satisfaction, and turnover intention: An empirical study in the Chinese public sector", Social Behavior and Personality, Vol.38(5), pp. 615-626.

Lum, L., Kervin, J., Clark, K., Reid, F., \& Sirola, W. (1998). "Explaining nursing turnover intent: Job satisfaction, pay satisfaction, or organizational commitment?", Journal of Organizational Behavior, Vol.19, pp. 305-320.

Masterson, S. S., Lewis, K., Goldman, B. M., Taylor, M. S., (2000). "Integrating justice and social exchange: The differing effects of fair procedures and treatment of work relationships", Academy of Management Journal, Vol.43, pp. 738-748.

McFarlin, D. B. and Sweeney, P. D. (1992). "Distributive and procedural justice as predictors of satisfaction with personal and organizational outcomes", Academy of Management Journal, Vol.35, pp. 626-637.

Moynihan, D. P. \& Pandey, S. K. (2007). "The ties that bind: Social networks, person-organization value fit, and turnover intention", Journal of Public Administration Research and Theory, Vol.18, pp. 205-227.

Niehoff B. P. and R. H. Moorman. (1993). "Justice as a mediator of the relationship between methods of monitoring and organizational citizenship behavior", Academy of Management Journal, Vol.36(3), pp. 527-556.

Nunnally, J. (1978). Psychometric Theory, New-York: McGraw-Hill.

Nunnally, J. C. and Bernstein, I. H. (1994). Psychometric Theory (3rd ed.), New-York: McGraw-Hill.

Ogilvie, J. R. (1986). "The role of human resource management practices in predicting organizational commitment", Group and Organization Studies, Vol.11, pp. 335-359.

Pfeffer, J. and Langton, N. (1993). "The effects of wage dispersion on satisfaction, productivity and working collaboratively: Evidence from college and university faculty", Administration Science Quarterly, Vol.38(3), pp. 382-407.

Podsakoff, P. M., MacKenzie, S. B., Lee, J. Y., \& Podsakoff, N. P. (2003). "Common method biases in behavioral research: A critical review of the literature and recommended remedies", Journal of Applied Psychology, Vol.88, pp. 879-903.

Rousseau, D. M. (2004). "Psychological contracts in the workplace: understanding the ties that motivate", Academy of Management Executive, Vol.18(1), pp.120-127.

Sabbagh, C., Yechezkel, D. and Nura, R. (1994). "The structure of social justice judgements: A facet approach”, Social Psychology Quarterly, Vol.57, pp. 244-261.

Samad, S. (2006a). "Predicting turnover intentions: The case of Malaysian government doctors", Journal of American Academy of Business, Vol.8(2), pp. 113-120.

Samad, S. (2006b). "Procedural and distributive justice: Differential effects on employee's work outcomes", The Business Review, Vol.5(2), pp. 212-219. 
Sashkin, M., Williams, R. L. (1990). "Does fairness make a difference?”, Organizational Dynamics, Vol.9, pp. 56-71.

Schappe, S. P. (1998). "Understanding employee job satisfaction: The importance of procedural and distributive justice", Journal of Business and Psychology, Vol.12(4), pp. 493-503.

Schwab, D. P. (2005). Research Methods for Organizational Studies (2nd ed.), NJ: Lawrence-Erlbaum.

Tett, R. P., \& Meyer, J. P. (1993). "Job satisfaction, organizational commitment, turnover intention, and turnover: Path analyses based on meta-analytical findings", Personnel Psychology, Vol.46(2), pp. 259293.

Thomas, S. L. and Bretz, R. D. (1994). "Research and practice in performance appraisal: Evaluating employee performance in America's largest companies", SAM Advanced Management Journal, Vol.4, pp. 28-34.

Wang, C. Y., Chen, M., Hyde, B. \& Hsieh, L. (2010). "Chinese employees' work values and turnover intentions in multinational companies: The mediating effect of pay satisfaction", Social Behavior and Personality, Vol.38(7), pp. 871-894.

Welbourne, T. M., Balkin, D. B. and Gomez-Mejia L. R. (1995). "Gain sharing and mutual monitoring: A combined agency-organizational justice interpretation", Academy of Management Journal, Vol.40, pp. 82-111.

Williams, L. J., \& Hazer, J. T. (1986). "Antecedents and consequences of satisfaction and commitment in turnover models: A reanalysis using latent variable structural equation methods", Journal of Applied Psychology, Vol.71(2), pp. 219-231.

Zehir, C., Altindag, E. and Acar, A. Z. (2011). "The effects of relationship orientation through innovation orientation on firm performance: An empirical study on Turkish family-owned firms", 7th International Strategic Management Conference Proceedings Book, pp. 883-893. 